\section{Kastamonu Eğitim Dergisi Kastamonu Education Journal}

Eylül 2019 Cilt:27 Sayı:6

kefdergi.kastamonu.edu.tr
Başvuru Tarihi/Received: 25.09.2018

Kabul Tarihi/Accepted: 01.02.2019

DOI: 10.24106/kefdergi.3357

\title{
Öğretmen Adaylarının Duygusal Zekâları ile Problem Çözme Yaklaşımları
} Arasındaki İlişki

\section{The Relationship between Prospective Teachers' Emotional Intelligence and Problem Solving Approaches}

\section{Öz}

\author{
Mecit ASLAN ${ }^{1}$
}

Bu çalışmanın amacı öğretmen adaylarının duygusal zekâları ile problem çözme yaklaşımları arasındaki ilişkiyi belirlemektir. Tarama modelinde gerçekleştirilen çalışma Van Yüzüncü Yıl Üniversitesi Eğitim Fakültesinde öğrenim gören 335 öğretmen adayı ile yürütülmüştür. Çalışmada veri toplama aracı olarak "Problem Çözme Envanteri" ve "Bar-On Duygusal Zekâ Ölçeği" kullanılmıştr. Elde edilen verilerin analizinde ise betimsel istatistikler, Pearson momentler çarpımı korelasyon analizi ve basamaklı regresyon analizi kullanılmıştır. Çalışma sonucunda, öğretmen adaylarının duygusal zekâ ve problem çözme puanlarının iyi düzeyde olduğu belirlenmiştir. Ayrıca, duygusal zekâ ve problem çözme arasında pozitif yönde anlamlı ilişki olduğu ve duygusal zekânın problem çözmeyi \%14 oranında açıkladığı ortaya çıkmıştır. Son olarak, problem çözme yaklaşımlarının duygusal zekâ boyutları tarafindan açıklandığı tespit edilmiştir.

Anahtar Kelimeler: öğretmen adayları, duygusal zekâ, problem çözme, problem çözme yaklaşımları

\section{Abstract}

The purpose of this study is to determine the relationship between prospective teachers' emotional intelligence and problem solving skills. The study carried out in the screening model was conducted with 335 prospective teachers studying at Van Yüzüncü Yıl University Faculty of Education. "Problem Solving Inventory" and "Bar-On Emotional Intelligence Scale" were used to collect data in the study. Descriptive statistics, Pearson correlation analysis and stepwise regression analysis were used in the analysis of the obtained data. As a result of the study, it has been determined that the prospective teachers' emotional intelligence and problem solving scores are at a good level. Moreover, it was found that emotional intelligence and problem solving were significantly and positively related and emotional intelligence predicted problem solving by $14 \%$. Finally, it has been found that problem-solving approaches are predicted by emotional intelligence dimensions.

Keywords: prospective teachers, emotional intelligence, problem solving, problem solving approaches 


\section{Extended Abstract}

Introduction: Today, individuals face various problems that vary depending on circumstances, needs and expectations (Tümkaya \& iflazoğlu, 2000). Individuals are happy, peaceful and healthy to the extent that they can solve these problems. Therefore, it can be said that people's success and enjoyment in life are related to their ability to solve the problems they encounter most appropriately (Saracaloğlu, Serin \& Bozkurt, 2001). Problem solving can be defined as a set of cognitive, affective, and behavioral processes that are conducted to meet various needs and to cope with challenges. Problem solving is not simple cognitive process (Heppner \& Krauskopf, 1987, p. 375); it is a highly complex, dynamic, interactive and progressive process. In the problem solving process, critical thinking and communication skills (Morreale, Osborn \& Pearson, 2000) are used to analyze and solve a problem in everyday life, and new solutions beyond the use of learners are being developed (Korkut, 2002).

It is seen that there are various studies (Deniz, 2004; Dixon, Heppner \& Anderson, 1991; D'zurilla, Chang, Nottingham \& Faccini, 1998; D'Zurilla, Chang \& Sanna, 2003; Sardoğan, Karahan \& Kaygusuz, 2006) on the relationship between problem solving and various variables. However, the relationship between emotional intelligence and problem solving approaches is lacking. In this framework, the aim of this study is to determine the relationship between prospective teachers' emotional intelligence and problem solving approaches.

Method: This study was conducted with the relational screening model. The research was carried out with 335 prospective teachers at Van Yüzüncü Yıl University Faculty of Education. 197 of the prospective teachers participating in the study were female and 138 were male. 114 of them are first class, 80 are second class, 92 are third class and 49 are fourth grade students. 83 of the participants are in Basic Education Department, 122 in Turkish and Social Sciences Education Department, 70 in Mathematics and Science Education Department, 34 in Computer and Instructional Technology Education Department and 26 in Fine Arts Education Department. "Problem Solving Inventory" developed by Heppner \& Peterson (1982), adapted Turkish culture by Şahin, Şahin \& Heppner (1993) and "Bar-On Emotional Intelligence Scale" adapted Turkish culture by Acar (2001) were used to collect data in the study. In the analysis of data collected, descriptive statistics, Pearson correlation coefficient and stepwise regression analysis were used by SPSS packet program.

Findings: The mean of the problem solving of the prospective teachers found as 2.78 . When the scores on the emotional intelligence of the trainees are examined, it is seen that the mean of general mood dimension is 2.36 , the mean of stress management dimension is 2.93 , the mean of adaptability dimension is 2.61 , the mean of interpersonal dimension is 2.16 and the mean of intrapersonal dimension is 2.47 . The mean of the scores obtained from the total of the emotional intelligence scale was determined as 2.48 . When the relationships between emotional intelligence and problem solving is analyzed, it is seen that there is a low (positively) correlation between problem solving and general mood, stress management and intrapersonal dimensions, and there is a moderate (positively) correlation between problem solving and adaptability, interpersonal dimensions, and total scale scores. Finally, it was found that adaptability $(\beta=.273)$ and interpersonal $(\beta=.165)$ dimensions were significant predictor of problem-solving.

Results and Discussion: As a result of the study, it has been determined that the problem solving of prospective teachers are at good level. In the study conducted by Saracaloğlu, Yenice \& Karasakaloğlu (2009), it was found that the problem-solving skills of the classroom prospective teachers were sufficient. Similarly, it has been determined the emotional intelligence of prospective teachers at a good level. When examined from the perspective of sub-dimensions, it was found that they were at "good" level in the dimensions of general mood, interpersonal and intrapersonal, and at "moderate" level in stress management and adaptability dimensions. Morever, it was concluded that there was a significant relationship between emotional intelligence and problem solving skills of prospective teachers, emotional intelligence predicted problem solving at $14 \%$ level, and all problem-solving approaches are predicted by emotional intelligence dimensions. Similarly, İşmen (2001) found a moderate relationship between positive emotional intelligence and perceived problem solving skills in the study conducted with undergraduate and non-thesis graduate students. A study by Deniz and Yilmaz (2016) also found that a low and moderate correlation was found between university students' emotional intelligence and problem-focused stress coping styles. 


\section{Giriş}

Problem, bireyin amacına ulaşmasını engelleyen, rahatsızlık uyandıran ve çatışmaya neden olan her şeydir. Bu anlamda problemin kapsamı oldukça geniştir (Morgan, 1974). Problem, bir bireyin içinde bulunduğu karmaşık durumlar olarak da ifade edilebilir. Bu anlamda kişiye yöneltilen bir soru, öğretmenlerin verdiği ödevler, enflasyon, savaş vb. pek çok durumu problem kategorisinde değerlendirmek mümkündür (Gelbal, 1991). Günümüzde bireyler koşullara, gereksinimlere ve beklentilere bağlı olarak değişiklik gösteren çeşitli problemlerle karşı karşıya kalmaktadır (Tümkaya \& íflazoğlu, 2000). Bireyler karşılaştkları bu problemleri çözebildikleri ölçüde mutlu, huzurlu ve sağlıklı olmaktadırlar. Dolayısıyla, insanların başarısı ve yaşamdan zevk almaları karşılaştkları problemleri en uygun şekilde çözme becerileriyle ilişkili olduğu söylenebilir (Saracaloğlu, Serin \& Bozkurt, 2001). Problem çözme, çeşitli ihtiyaçları karşılama ve zorluklarla başa çıkma amacıyla gerçekleştirilen bir dizi bilişsel, duyuşsal ve davranışsal işlem olarak tanımlanabilir. Problem çözme bilginin bilişsel olarak rasyonel, mantkksal olarak basitçe işlenmesi değil; oldukça karmaşık, dinamik, etkileşimli ve aşamalı bir süreç olarak kavramsallaştrılmıştır (Heppner \& Krauskopf, 1987; s. 375). Problem çözme sürecinde günlük yaşamdaki bir sorunu analiz etmek ve çözüm bulmak için eleştirel düşünmenin ve iletişim becerilerinin uygulanması (Morreale, Osborn \& Pearson, 2000) ve öğrenilenlerin kullanılmasının ötesinde yeni çözümler üretilmesi söz konusudur (Korkut, 2002). Problem çözme yaşantlar yoluyla öğrenilen bazı kuralların basit bir uygulaması değil; bilişsel, duyuşsal ve psikomotor beceri ve özellikleri kullanmayı gerektiren karmaşık bir süreçtir (Korkut, 2002).

Problem çözme sürecinde çözülmesi gereken bütün problemler aynı güçlükte değildir ve her zaman aynı yolla çözülememektedir. Bazı problemler çok karmaşık oldukları için çözümleri zor iken, bazılarının çözümü daha az çaba gerektirmektedir. Bazı problemlerin çözümünde önceki alışkanlıklar ve deneyimler yeterli olurken bazılarında yetersiz kalmaktadır. Bazı problemlerin çözümünde deneme-yanılma yöntemi kullanılırken bazılarında bilimsel yöntemin kullanılması gerekmektedir (Üstün \& Bozkurt, 2003). Problem çözme sürecinde bilimsel yöntem kullanılırken bazı aşamaların takip edilmesi gerekmektedir. Problem çözme sürecinin birinci aşamasında kişinin kendisinde rahatsızlık uyandıran problemin farkına varması beklenmektedir. İkinci aşamada, problemin tanımlanması, problem durumunun ayrıntılı olarak ortaya konulması, üçüncü aşamada, problemin çözümüne yönelik olası çözüm yollarının belirlenmesi gerekmektedir. Bu aşamaları bu alternatiflerin değerlendirilmesi ve geliştirilmesi takip etmektedir. Son aşamada, deney ve gözlem sonuçlarına göre çözüm önerisinin kabul veya reddedilmesi gelmektedir (Dewey, 1997, s. 72; Gelbal, 1991). Polya (2004) ise problem çözme basamaklarını (i) problemi anlama, (ii) plan yapma (iii) planı uygulama ve (iv) geriye dönüp bakma/ değerlendirme şeklinde ifade etmiştir. Polya'nın (2004) yaklaşımında öncelikle çözülmesi gereken problemin tüm boyutlarıyla anlaşıması gerekmektedir. Sonraki aşamada tüm boyutları ile ortaya konulan problemin çözümü için yapılacak çalışmaların planlanması ve planlanan çözümün hayata geçirilmesi öngörülmektedir. Bu yaklaşımda son olarak çözümün ne derece işe yaradığı ile ilgili bir değerlendirme yapılması gerekmektedir. Dolayısıyla, problem çözme sürecinin/basamaklarının farklı araştırmacılar tarafından farklı şekilde ele alındığı söylenebilir.

Problem çözme sürecini etkileyen pek çok faktör bulunmaktadır. Problemin kişinin yaşı, problemin çözümü için gerekli ön bilgilere sahip olma düzeyi, yeteneği, sağlık durumu, problemi çözmeye yönelik tutumu, problemi çözmenin sağlayacağı fayda, kişilik özellikleri vb. faktörlerin problemin çözümünde etkili olduğu söylenebilir (Gelbal, 1991). Ayrıca, bireyin duyguları, inançları ve değerleri problem çözme sürecini etkilemektedir (Dökmen, 2008). Problem çözme sürecinde bilişsel özellikler kadar duygusal özelliklerin de etkili olduğu söylenebilir. Duygusal reaksiyonlar problem çözme sürecinde nasıl düşünüleceği ve davranılacağı üzerinde kritik bir rol oynamaktadır. Bu nedenle duygusal başa çıkma stratejilerini kullanmak bir problemi çözmede çok etkili olabilir. Duygusal başa çıkma stratejilerinin örnekleri arasında, pasif kabul, içten düşünme, teslimiyet, duyguları çözme ve maneviyat destekleme bulunmaktadır (Heppner \& Krauskopf, 1987; s. 415). Bu görüşler teorik olarak problem çözme sürecinde duyguların ve duygusal zekânın önemli bir işlev gördüğünü göstermektedir.

Duygular birey için olumlu ya da olumsuz bir anlamı olan içsel veya dışsal olaylara verilen organize yanıtlar olarak ortaya çıkmaktadır. Duygusal zekâ ise, bir problemi çözmek ve davranışları düzenlemek için kişinin ve başkalarının hislerini ve duygularını anlama, onları ayırt etme ve bu bilgiyi kullanma becerisini içeren sosyal zekânın alt boyutu olarak tanımlanabilir. Bu yönüyle duygusal zekâ Gardner tarafindan ortaya konulan çoklu zekâ kuramının bir alt kümesidir (Salovey \& Mayer, 1990). Başka bir deyişle, duygusal zekâ, duygu yüklü bilgiyi yetkin bir şekilde işleme koyma ve problem çözme gibi bilişsel etkinlikleri yönlendirmede ve enerjiyi gerekli davranışlara odaklamada kullanma yeteneğini ifade eder (Salovey, Mayer \& Caruso, 2002). Duygusal zekâ, bireyin davranışlarına yön veren ihtiyaçları, dürtüleri ve değerleri temsil eden, insanlar arasındaki ilişkilerin ve iş hayatında başarının belirleyicisi olan bir özelliktir (Güllüce \& İşcan, 2010). Duygusal zekâ, IQ (Intelligence Quotient) için bir alternatif değil, tamamlayıcı bir unsur olarak görülmelidir. Bu iki zekâ türü birbirinden ayrılması mümkün olmayan karmaşık beceriler bütünü olarak ifade edilebilir (Erdem, ilğan ve Çelik, 2013).

Salovey ve Mayer (1997) dört boyutlu bir duygusal zekâ modeli ortaya atmışlardır. Bu modelde duygusal zekânın (i) 
kendisinin ve başkalarının duygularını algılama yeteneği, (ii) düşünmeyi kolaylaştırmak için duyguları kullanma yeteneği, (iii) duygusal anlamları anlama yeteneği ve (iv) duyguları yönetme yeteneğini içerdiği ifade edilmektedir. Birinci boyut sözlü olmayan duygu ifadeleri ile ilgilidir. Biyologlar ve psikologlar duyguların iletişimde güçlü bir iletişim aracı olduğunu; mutluluk, hüzün, öfke ve korku gibi duyguların insanlarda evrensel olarak tanındığını ifade etmektedir. Dolayısıyla birinci boyutta karşıdakinin sesinden veya yüzünden hangi duyguda olduğunun algılanması önemli bir başlangıç noktası olarak kabul edilmektedir. İkinci boyutta duyguların düşünceye rehberlik ettiği ve düşünmeyi teşvik ettiği ifade edilmektedir. Çünkü bilişselcilere göre duygusal olarak tepki verdiğimiz şey dikkatimizi çeken şeydir. Dolayısıyla dikkat çeken şeyin üzerinde düşünmek daha mümkün olmaktadır. Üçüncü boyut duyguların içerdiği mesajları ve onlarla ilişkili eylemleri anlamayı içermektedir. Örneğin, mutluluk diğer insanlara katılma isteğini gösterirken, öfke başkalarına saldırma veya zarar verme arzusunu içermektedir. Son boyut olan dördüncü boyutta ise kişinin kendisinin veya başkasının duygularını düzenleme ve yönetme yeteneğine vurgu yapılmaktadır. Çünkü bu modelde duyguların yönetilebileceği varsayılmaktadır (Mayer, 2004).

Duygusal zekâ ile ilgili bir başka model Bar-On tarafindan ortaya atıımıştır. Bu modele göre duygusal zekâ, kendimizi ne kadar anladığımızı ve ifade ettiğimizi, başkalarını ne kadar anladığımızı ve onlarla ilişki kurduğumuzu ve günlük taleplerle nasıl başa çıktı̆̆ımıı belirleyen duygusal ve sosyal yeterlilikler, beceriler ve kolaylaştırıcıların bir kesitidir. Bu model beş temel bileşen içermektedir: (i) duyguları ve hisleri tanıma, anlama ve ifade etme yeteneği; (ii) başkalarının hislerini anlama ve onlarla ilişki kurma yeteneği; (iii) duyguları yönetme ve kontrol etme yeteneği; (iv) değişimi yönetme, kişisel ve kişilerarası sorunları uyarlama ve çözme yeteneği ve (v) olumlu etki üretme ve kendini motive etme yeteneği (BarOn, 2006). Duygusal zekâ ile ilgili alanyazın incelendiğinde problem çözme ile ilişkisine vurguların olduğu görülmektedir. Bununla birlikte kuramsal olarak ilişkili oldukları ifade edilen duygusal zekâ ile problem çözme arasındaki ilişkiye yönelik çalışmaların eksikliği göze çarpmaktadır.

\section{Araştırmanın Amacı ve Önemi}

Bu araştırmada öğretmen adaylarının duygusal zekâları ile problem çözme yaklaşımları arasındaki ilişkinin belirlenmesi amaçlanmaktadır. Bu amaç doğrultusunda aşağıdaki sorulara yanıt aranmıştır:

1. Öğretmen adayları problem çözme yaklaşımlarını ne düzeyde kullanmaktadır?

2. Öğretmen adaylarının duygusal zekâları ne düzeydedir?

3. Öğretmen adaylarının duygusal zekâları ile problem çözme yaklaşımları arasında anlamlı bir ilişki var mıdır?

4. Öğretmen adaylarının duygusal zekâları problem çözme yaklaşımlarını anlamlı düzeyde yordamakta mıdır?

Problem çözme ile çeşitli değişkenler arasındaki ilişkiye yönelik yerli ve yabancı alanyazında çeşitli çalışmaların (Deniz, 2004; Dixon, Heppner \& Anderson, 1991; D'zurilla, Chang, Nottingham \& Faccini, 1998; D’Zurilla, Chang \& Sanna, 2003; Sardoğan, Karahan \& Kaygusuz, 2006) yapıldığı görülmektedir. Bu çalışmalarda problem çözmenin karar verme, yaşam stresi, intihar düşüncesi, umutsuzluk, mutsuzluk, depresyon, özsaygı, saldırganlık ve öğrenme stratejileri ile ilişkisinin ele alındığı görülmektedir. Bu çalışma yukarıda eksikliği ifade edilen problem çözme ve duygusal zekâ arasındaki ilişkiyi ampirik verilerle ortaya koyması ve bu yönüyle alanyazına katkıda bulunması nedeniyle önem arz etmektedir.

Öğretmen adayları yarının öğretmenleri olarak eğitim sistemi için önemli bir yer teşkil etmektedir. Bu nedenle öğretmen adaylarının her yönden donanımlı olmaları, bilişsel yeterliklerinin yanında duygusal zekâ noktasında da yeterli olmaları gerekmektedir. Böylece öğretmen adayları gerek günlük yaşamlarında gerekse de eğitim sürecinde karşılaşttkları problemleri daha etkin bir şekilde çözebileceklerdir. İlgili alınyazın incelendiğinde, öğretmen adaylarının duygusal zekâları ile problem çözme becerileri arasındaki ilişkiyi ele alan çalışmaların eksikliği göze çarpmaktadır. Bu çalışma öğretmen adaylarının duygusal zekâ düzeylerini ve problem çözme yaklaşımlarını belirlemesi, böylece henüz hizmet öncesi dönemde varsa bu konudaki eksikleri ortaya koyması, yaşanan sorunlara çözüm önerisi sunması ve ilgili alanyazına katkı sunması açısından önem arz etmektedir.

\section{Yöntem}

\section{Araştırmanın Modeli}

Öğretmen adaylarının duygusal zekâları ile problem çözme yaklaşımları arasındaki ilişkinin incelendiği bu çalışma tarama modellerinden ilişkisel tarama modeli ile yürütülmüştür. ilişskisel tarama modelinde iki veya daha fazla değişken arasındaki ilişkinin belirlenmesi amaçlanmaktadır (Karasar, 2012). 


\section{Çalışma Grubu}

Çalışma, Van Yüzüncü Yıl Üniversitesi Eğitim Fakültesinin farklı bölümlerinde öğrenim görmekte olan 335 öğretmen adayı ile yürütülmüştür. Çalışmaya katılan öğretmen adaylarının belirlenmesinde basit tesadüfi örnekleme yöntemi kullanılmıştır. Bu örnekleme yönteminde örnekleme oluşturulurken herhangi bir amaç güdülmez ve evrendeki her birimin seçilme ihtimali bağımsız ve eşittir (Balcı, 2010; Büyüköztürk vd., 2013). Örneklem grubunda yer alan öğretmen adaylarının kişisel özellikleri Tablo 1'de verilmiştir.

Tablo 1. Örneklem grubunda yer alan öğretmen adaylarının kişisel özellikleri

\begin{tabular}{|c|c|c|c|}
\hline \multicolumn{2}{|c|}{ Kişisel Özellikler } & Sayı (n) & Yüzde (\%) \\
\hline \multirow{2}{*}{ Cinsiyet } & Kadın & 197 & $\% 59$ \\
\hline & Erkek & 138 & $\% 41$ \\
\hline \multirow{4}{*}{ Sınıf Düzeyi } & Birinci sınıf & 114 & $\% 34$ \\
\hline & İkinci sınıf & 80 & $\% 24$ \\
\hline & Üçüncü sınıf & 92 & $\% 27$ \\
\hline & Dördüncü sınıf & 49 & $\% 15$ \\
\hline \multirow{5}{*}{ Bölüm } & Temel Eğitim & 83 & $\% 25$ \\
\hline & Türkçe ve Sosyal Bilimler Eğitimi & 122 & $\% 36$ \\
\hline & Matematik ve Fen Bilimleri Eğitimi & 70 & $\% 21$ \\
\hline & ВÖTE & 34 & $\% 10$ \\
\hline & Güzel Sanatlar Eğitimi & 26 & $\% 8$ \\
\hline
\end{tabular}

Tabloda görüldüğü üzere, çalışmaya katılan öğretmen adaylarının 197'si kadın ve 138'i erkek iken; 114'ü birinci sınıf, 80'i i ikinci sınıf, 92'si üçüncü sınıf ve 49'u dördüncü sınıf öğrencisidir. Katlımcıların 83'ü Temel Eğitim, 122'si Türkçe ve Sosyal Bilimler Eğitimi, 70'i Matematik ve Fen Bilimleri Eğitimi, 34'ü BÖTE ve 26'sı Güzel Sanatlar Eğitimi Bölümünde öğrenim görmektedir.

\section{Veri Toplama Araçları}

Araştırmada verilerin toplanabilmesi için "Problem Çözme Envanteri" ve "Bar-On Duygusal Zekâ Ölçeği" kullanılmıştır.

Problem Çözme Envanteri. Çalışmada Heppner ve Peterson (1982) tarafindan geliştirilen; Şahin, Şahin ve Heppner (1993) tarafindan Türkçeye uyarlanan Problem Çözme Envanteri kullanılmıştr. Ölçek 35 madde ve alt boyuttan (aceleci yaklaşım, düşünen yaklaşım, kaçıngan yaklaşım, değerlendirici yaklaşım, kendine güvenli yaklaşım ve planlı yaklaşım) oluşmaktadır. Ölçek altılı likert (1-Her zaman, 2-Çoğunlukla, 3-Sık sık, 4-Ara sıra, 5-Nadiren, 6-Hiçbir zaman) türünde geliştirilmiştir. Uyarlama çalışmasında ölçeğin toplamı için iç tutarlık katsayısı 0.88 , aceleci yaklaşım için 0.78 , düşünen yaklaşım için 0.76 , kaçıngan yaklaşım için 0.74 , değerlendirici yaklaşım için 0.69 , kendine güvenli yaklaşım için 0.64 ve planlı yaklaşım için 0.59 olarak tespit edilmiştir. Bu çalışmada ölçeğin toplamı için güvenirlik kat sayısı 0.83 olarak bulunmuştur. Alt boyutlar açısından bakıldığında ise güvenirlik katsayıları aceleci yaklaşım, kendine güvenli yaklaşım ve planlı yaklaşım için 0.64 , düşünen yaklaşım için 0.73 , kaçıngan yaklaşım için 0.83 ve değerlendirici yaklaşım için 0.65 olarak tespit edilmiştir.

Bar-On Duygusal Zekâ Ölçeği. Araştırmada kullanılan bir diğer veri toplama aracı Acar (2001) tarafindan Türkçeye uyarlanan Bar-On Duygusal Zekâ Ölçeğidir. Beşli likert (1-Tamamen katilıyorum, 2-Katlıyorum, 3-Kararsızım, 4-Katılmıyorum, 5-Kesinlikle katılmıyorum) türündeki ölçeğin orijinalinde 133 madde bulunurken uyarlama çalışmasında 5 alt boyut (genel ruh durumu, stres yönetimi, uyumluluk, kişilerarası beceriler, kişisel beceriler) ve 87 maddeden oluşan bir ölçek elde edilmiştir. Uyarlama çalışmasında ölçeğin toplamı için güvenirlik katsayısı 0.92, alt boyutlardan kişisel beceriler için 0.83 , kişilerarası beceriler için 0.77 , uyumluluk için 0.65 , stres yönetimi için 0.73 ve genel ruh durumu için 0.75 olarak bulunmuştur. Bu çalışmada ölçeğin toplamı için güvenirlik katsayısı 0.88 olarak tespit edilmiştir. Alt boyutlar açısından incelendiğinde ise güvenirlik katsayısı kişisel beceriler için 0.78 , kişilerarası beceriler için 0.68 , stres yönetimi için 0.64 , uyumluluk için 0.54 ve genel ruh durumu için 0.63 olarak tespit edilmiştir.

\section{Verilerin Analizi}

Toplanan verilerin analizinde SPSS paket programı kullanılmıştır. Öğretmen adaylarının problem çözme ve duygusal zekâ puanlarının ne düzeyde olduğunu belirlemek amacıyla betimsel istatistiklerden (aritmetik ortalama ve standart sapma) yararlanılmıştr. Her iki ölçeğin yapısı gereği düşük puanlar yüksek problem çözme becerisi ve yüksek duygusal zekâ anlamına gelmektedir. Öğretmen adaylarının problem çözme yaklaşımlarından aldıkları ortalamalar; ölçek altılı likert türünde olduğu için 5/6=0.83 hesaplamasının sonucuna göre "1.00-1.83" her zaman, "1.84-2.66" çoğunlukla, 
"2.67-3.50" sık sık, "3.51-4.33" ara sıra, "4.34-5.16" nadiren, "5.17-6.00" hiçbir zaman şeklinde yorumlanmıştr. Katılımcıların duygusal zekâ puanları ise; ölçek beşli likert türünde olduğu için $4 / 5=0.80$ hesaplamasının sonucuna göre " 1.00 1.80" çok iyi, "1.81-2.60" iyi, "2.61-3.40" orta, "3.41-4.20" düşük, "4.21-5.00" çok düşük şeklinde yorumlanmıştır.

Öğretmen adaylarının problem çözme yaklaşımları ile duygusal zekâları arasındaki ilişkilerin belirlenmesi için öncelikle verilerin normal dağııı gösterip göstermediği kontrol edilmiştir. Bu süreçte çarpıklık (skewness) ve basıklık (kurtosis) değerlerine bakılmıştır. Yapılan analiz sonucu ulaşılan değerler Tablo 2'de verilmiştir.

Tablo 2. Normallik analizi sonuçları

\begin{tabular}{lcclcc}
\hline Problem Çözme & Çarpıklık & Basıklık & Duygusal Zekâ & Çarpıklık & Basıklık \\
\hline Aceleci yaklaşım & -.456 & .282 & Genel ruh durumu & -.200 & .871 \\
Düşünen yaklaşım & .683 & .237 & Stres yönetimi & -.045 & -.098 \\
Kaçıngan yaklaşım & -.664 & .535 & Uyumluluk & .129 & .366 \\
Değerlendirici yaklaşım & .436 & -.421 & Kişilerarası beceriler & -.523 & 1.92 \\
Kendine güvenli yaklaşım & .414 & .311 & Kişisel beceriler & .034 & 1.113 \\
Planlı yaklaşım & .585 & .242 & Duygusal Zekâ (Toplam) & .045 & 1.274 \\
Problem Çözme (Toplam) & .515 & .615 & & & \\
\hline
\end{tabular}

Tabloda görüldüğü üzere, çarpıklık basıklık değerlerinin +1.96 ile -1.96 arasında değişmesi nedeniyle verilerin normal dağılım gösterdiği kabul edilmiştir (Karaalioğlu, 2015). Bu çerçevede değişkenler arasındaki ilişkilerin belirlenmesi için Pearson momentler çarpımı korelasyon katsayısı kullanıımıştır. Duygusal zekâ puanlarının problem çözme yaklaşımlarını yordayıp yordamadığını belirlemek için ise basamaklı (stepwise) regresyon analizine başvurulmuştur.

\section{Bulgular}

Bu başlık altında araştırmanın amacı doğrultusunda elde edilen bulgulara yer verilmiştir. Öğretmen adaylarının problem çözme yaklaşımlarına yönelik betimsel istatistikler Tablo 3'te verilmiştir.

Tablo 3. Öğretmen adaylarının problem çözme yaklaşımlarına ilişkin betimsel istatistikler

\begin{tabular}{lccc}
\hline Problem Çözme Yaklaşımı & $\mathbf{N}$ & $\overline{\mathbf{x}}$ & Ss \\
\hline Aceleci yaklaşım & 335 & 3.87 & .67 \\
Düşünen yaklaşım & 335 & 2.58 & .85 \\
Kaçıngan yaklaşım & 335 & 4.52 & .91 \\
Değerlendirici yaklaşım & 335 & 2.68 & 1.04 \\
Kendine güvenli yaklaşım & 335 & 2.69 & .78 \\
Planlı yaklaşım & 335 & 2.57 & .87 \\
Problem Çözme (Toplam) & 335 & 2.78 & .55 \\
\hline
\end{tabular}

Öğretmen adaylarının kullandıkları problem çözme yaklaşımları incelendiğinde, en sık kullandıkları yaklaşımların sırasıyla planlı yaklaşım ( $\bar{x}=2.57)$, düşünen yaklaşım $(\bar{x}=2.58)$, değerlendirici yaklaşım $(\bar{x}=2.68)$, kendine güvenli yaklaşım $(\bar{x}=2.69)$, aceleci yaklaşım ( $\bar{x}=3.87)$ ve kaçıngan yaklaşım $(\bar{x}=4.52)$ şeklindedir. Bu değerler öğretmen adaylarının planlı yaklaşım ve düşünen yaklaşımı "Çoğunlukla", değerlendirici yaklaşım ve kendine güvenli yaklaşımı "Sık sık", aceleci yaklaşımı "Ara sıra” ve kaçıngan yaklaşımı "Nadiren" kullandıkları anlaşılmaktadır. Öğretmen adaylarının ölçek toplamından aldıkları puanların ortalaması ise 2.78 olarak tespit edilmiştir.

Öğretmen adaylarının duygusal zekâ puanlarına yönelik betimsel istatistikler Tablo 4'te verilmiştir.

Tablo 4. Öğretmen adaylarının duygusal zekâ puanlarına ilişkin betimsel istatistikler

\begin{tabular}{lccc}
\hline \multicolumn{1}{c}{ Duygusal Zekâ } & N & $\overline{\mathbf{x}}$ & Ss \\
\hline Genel ruh durumu & 335 & 2.36 & .50 \\
Stres yönetimi & 335 & 2.93 & .53 \\
Uyumluluk & 335 & 2.61 & .41
\end{tabular}

| Kastamonu Eğitim Dergisi, 27(6), 2019| 


\begin{tabular}{lccc}
\hline \multicolumn{1}{c}{ Duygusal Zekâ } & N & $\overline{\mathbf{x}}$ & Ss \\
\hline Kişilerarası beceriler & 335 & 2.16 & .44 \\
Kişisel beceriler & 335 & 2.47 & .43 \\
Duygusal Zekâ (Toplam) & 335 & 2.48 & .34 \\
\hline
\end{tabular}

Öğretmen adaylarının duygusal zekâları ile ilgili elde edilen puanlar incelendiğinde, genel ruh durumu boyutunun 2.36, stres yönetimi boyutunun 2.93, uyumluluk boyutunun 2.61, kişilerarası beceriler boyutunun 2.16 ve kişisel beceriler boyutunun 2.47 aritmetik ortalamasına sahip olduğu görülmektedir. Ölçeğin toplamından elde edilen puanların aritmetik ortalaması ise, 2.48 olarak tespit edilmiştir. Bu ortalamalar öğretmen adaylarının genel ruh durumu, kişilerarası beceriler ve kişisel becerileri boyutlarında "iyi", stres yönetimi ve uyumluluk boyutlarında ise "orta" düzeyde olduklarını göstermektedir. Öğretmen adaylarının ölçeği toplamından elde ettikleri duygusal zekâ puanlarının "iyi" düzeyde olduğu tespit edilmiştir.

Öğretmen adaylarının duygusal zekâları ile problem çözme yaklaşımları arasındaki ilişkiye yönelik analiz sonuçları Tablo 5'te verilmiştir.

Tablo 5. Duygusal zekâ ve problem çözme yaklaşımları arasındaki ilişkiyi belirlemek amacıyla gerçekleştirilen Pearson çarpım momentler korelasyon analizi sonuçları

$\begin{array}{lcccccc} & \begin{array}{c}\text { Genel ruh } \\ \text { durumu }\end{array} & \begin{array}{c}\text { Stres } \\ \text { yönetimi }\end{array} & \text { Uyumluluk } & \begin{array}{c}\text { Kişilerarası } \\ \text { beceriler }\end{array} & \begin{array}{c}\text { Kişisel } \\ \text { beceriler }\end{array} & \begin{array}{c}\text { Duygusal Zekâ } \\ \text { (Toplam) }\end{array} \\ \text { Aceleci yaklaşım } & .006 & -.062 & -.046 & -.038 & .117^{*} & .017 \\ \text { Düşünen yaklaşım } & .230^{* *} & .146^{* *} & .377^{* *} & .284^{* *} & .253^{* *} & .343^{* *} \\ \text { Kaçıngan yaklaşım } & -.149^{* *} & -.098 & -.225^{* *} & -.179^{* *} & -.074 & -.179^{* *} \\ \text { Değerlendirici yaklaşım } & .120^{*} & .093 & .249^{* *} & .213^{* *} & .197^{* *} & .239^{* *} \\ \text { Kendine güvenli yaklaşım } & .384^{* *} & .112^{*} & .342^{* *} & .365^{* *} & .454^{* *} & .466^{* *} \\ \text { Planlı yaklaşım } & .236^{* *} & .121^{*} & .274^{* *} & .192^{* *} & .219^{* *} & .278^{* *} \\ \text { Problem Çözme (Toplam) } & .266^{* *} & .150^{* *} & .357^{* *} & .303^{* *} & .255^{* *} & .353^{* *}\end{array}$

Öğretmen adaylarının problem çözme yaklaşımları ile duygusal zekâları arasındaki ilişkiye yönelik gerçekleştirilen analiz sonuçları incelendiğinde, aceleci yaklaşım ile kişisel beceriler arasında pozitif yönde ve düşük düzeyde bir ilişkinin olduğu görülmektedir. Düşünen yaklaşımın uyumluluk boyutu ve duygusal zekâ toplam puanı ile pozitif yönde ve orta düzeyde, diğer boyutlarla pozitif yönde düşük düzeyde bir ilişkiye sahip olduğu tespit edilmiştir. Kaçıngan yaklaşımın genel ruh durumu, uyumluluk, kişilerarası beceriler ve duygusal zekâ toplam puanı ile negatif yönde ve düşük düzeyde ilişkili olduğu belirlenmiştir. Değerlendirici yaklaşımın stres yönetimi dışındaki boyutlar ve duygusal zekâ toplam puanı ile pozitif yönde düşük düzeyde; kendine güvenli yaklaşımın stres yönetimi ile düşük düzeyde, geriye kalan boyutlar ve duygusal zekâ toplam puanı ile pozitif yönde orta düzeyde; planlı yaklaşımın tüm boyutlar ve duygusal zekâ toplam puanı ile pozitif yönde düşük düzeyde ilişkili olduğu görülmektedir. Son olarak, problem çözme btoplam puanının genel ruh durumu, stres yönetimi ve kişisel beceriler ile pozitif yönde düşük düzeyde geriye kalan boyutlar ve duygusal zekâ toplam puanı ile orta düzeyde ilişkili olduğu tespit edilmiştir.

Çalışma kapsamında öğretmen adaylarının problem çözme yaklaşımlarının yordanmasına yönelik analizler gerçekleştirilmiştir. Bu çerçevede problem çözme toplam puanlarının yordanmasına ilişkin yapılan basamaklı regresyon analizi sonuçlarına Tablo 6'da yer verilmiştir.

Tablo 6. Problem çözme toplam puanlarının yordanması amacıyla gerçekleştirilen basamaklı regresyon analizi sonuçları

\begin{tabular}{|c|c|c|c|c|c|c|}
\hline Model & Değişken & B & SH & $\beta$ & $t$ & $p$ \\
\hline \multirow{3}{*}{1} & (Sabit) & 1.542 & .180 & & 8.572 & .000 \\
\hline & Uyumluluk & .474 & .068 & .357 & 6.963 & .000 \\
\hline & $\mathrm{R}^{2}=.127$ & $\Delta \mathrm{R}^{2}=.124$ & $\mathrm{~F}_{(1.333)}=48.490 * *$ & & & \\
\hline \multirow{4}{*}{2} & (Sabit) & 1.383 & .187 & & 7.407 & .000 \\
\hline & Uyumluluk & .364 & .078 & .273 & 4.665 & .000 \\
\hline & Kişilerarası Beceriler & .207 & .074 & .165 & 2.821 & .005 \\
\hline & $\mathrm{R}^{2}=.148$ & $\Delta \mathrm{R}^{2}=.142$ & $\mathrm{~F}_{(2,332)}=28.730 * *$ & & & \\
\hline
\end{tabular}

** $p<.01, * p<.05$ 
Öğretmen adaylarının problem çözme toplam puanının yordanması amacıyla gerçekleştirilen analiz sonucuna göre uyumluluk ( $\beta=.273$ ) ve kişilerarası beceriler $(\beta=.165)$ problem çözmenin anlamlı yordayıcısıdır. İki aşamada gerçekleşen analizin birinci basamağına problem çözmeyi \%12 oranında açıklayan uyumluluk alınmıştır. i̇kinci basamağa uyumluk boyutu ile birlikte problem çözmeyi tek başına $\% 2$ oranında açıklama gücüne sahip olan kişilerarası beceriler boyutu alınmıştır. Bu iki boyutun birlikte problem çözmeyi \%14 oranında açıkladığı tespit edilmiştir.

Problem çözme yaklaşımlarından aceleci yaklaşımın yordanmasına ilişkin analiz sonuçları Tablo 7'de verilmiştir.

Tablo 7. Aceleci yaklaşımın yordanması amacıyla gerçekleştirilen basamaklı regresyon analizi sonuçları

\begin{tabular}{|c|c|c|c|c|c|c|}
\hline Model & Değişken & B & SH & $\beta$ & $t$ & $\mathbf{p}$ \\
\hline \multirow{3}{*}{1} & (Sabit) & 3.425 & .210 & & 16.298 & .000 \\
\hline & Kişisel Beceriler & .181 & .084 & .117 & 2.156 & .032 \\
\hline & $R^{2}=.014$ & $\Delta \mathrm{R}^{2}=.011$ & $F_{(1,333)}=4.647^{*}$ & & & \\
\hline \multirow{4}{*}{2} & (Sabit) & 3.591 & .217 & & 16.573 & .000 \\
\hline & Kişisel Beceriler & .373 & .108 & .242 & 3.437 & .001 \\
\hline & Kişilerarası Beceriler & -.297 & .108 & -.194 & -2.750 & .006 \\
\hline & $\mathrm{R}^{2}=.036$ & $\Delta R^{2}=.030$ & $\mathrm{~F}_{(2,332)}=6.151 * *$ & & & \\
\hline
\end{tabular}

Aceleci yaklaşımın yordanmasına ilişkin gerçekleştirilen basamaklı regresyon analizi sonucuna göre, kişisel beceriler $(\beta=.242)$ ve kişilerarası beceriler ( $\beta=-.194)$ aceleci yaklaşımın anlamlı bir yordayıcısıdır. İki basamakta gerçekleşen regresyon analizinin ilk basamağında kişisel becerilerin aceleci yaklaşımı \%1 oranında açıkladığı, ikinci basamakta kişisel beceriler ile birlikte kişilerarası beceriler birlikte aceleci yaklaşımı \%3 oranında açıkladığı görülmektedir.

Düşünen yaklaşımın yordanmasına ilişkin yapılan basamaklı regresyon analizi sonuçlarına Tablo 8'de yer verilmiştir.

Tablo 8. Düşünen yaklaşımın yordanması amacıyla gerçekleştirilen basamaklı regresyon analizi sonuçları

\begin{tabular}{|c|c|c|c|c|c|c|}
\hline Model & Değişken & B & SH & $\beta$ & t & p \\
\hline \multirow{3}{*}{1} & (Sabit) & .556 & .276 & & 2.015 & .045 \\
\hline & Uyumluluk & .775 & .104 & .377 & 7.426 & .000 \\
\hline & $\mathrm{R}^{2}=.142$ & $\Delta R^{2}=.139$ & $\mathrm{~F}_{(1333)}=55.144 * *$ & & & \\
\hline \multirow{4}{*}{2} & (Sabit) & .367 & .288 & & 1.275 & .203 \\
\hline & Uyumluluk & .644 & .120 & .313 & 5.362 & .000 \\
\hline & Kişilerarası Beceriler & .246 & .113 & .127 & 2.175 & .030 \\
\hline & $\mathrm{R}^{2}=.154$ & $\Delta R^{2}=.149$ & $\mathrm{~F}_{(2,332)}=30.247 * *$ & & & \\
\hline
\end{tabular}

Düşünen yaklaşımın yordanmasına ilişkin gerçekleştirilen basamaklı regresyon analizi sonucuna göre, uyumluluk $(\beta=.313)$ ve kişilerarası beceriler ( $\beta=-.127)$ aceleci yaklaşımın anlamlı bir yordayıcısıdır. İki basamakta gerçekleşen regresyon analizinin ilk basamağında uyumluluk aceleci yaklaşımı \%14 oranında açıklarken, ikinci basamakta uyumluluk ile birlikte kişilerarası yaklaşımın birlikte düşünen yaklaşımı \%15 oranında açıkladığı görülmektedir.

Tablo 9'da kaçıngan yaklaşımın yordanmasına ilişkin yapılan basamaklı regresyon analizi sonuçlarına yer verilmiştir.

Tablo 9. Kaçıngan yaklaşımın yordanması amacıyla gerçekleştirilen basamaklı regresyon analizi sonuçları

\begin{tabular}{|c|c|c|c|c|c|c|c|}
\hline Model & $\begin{array}{l}\text { Değişken } \\
\text { (Sabit) }\end{array}$ & & $\begin{array}{c}\text { B } \\
5.813\end{array}$ & $\begin{array}{l}\text { SH } \\
.311\end{array}$ & $\beta$ & $\begin{array}{c}\mathbf{t} \\
18.709\end{array}$ & $\begin{array}{c}\mathbf{p} \\
.000\end{array}$ \\
\hline 1 & $\begin{array}{l}\text { Uyumluluk } \\
\mathrm{R}=.225\end{array}$ & $\mathrm{R}^{2}=.051$ & $\begin{array}{c}-.496 \\
\Delta R^{2}=.048\end{array}$ & $\begin{array}{c}.118 \\
F_{(1,333)}=17.745^{* *}\end{array}$ & -.225 & -4.213 & .000 \\
\hline
\end{tabular}

Tabloda görüldüğü üzere, kaçıngan yaklaşımın yordanmasına ilişkin gerçekleştirilen basamaklı regresyon analizi sonucuna göre, uyumluluk ( $\beta=-.225$ ) kaçıngan yaklaşımın anlamlı bir yordayıcısıdır. Bir basamakta gerçekleşen regresyon analizinin sonucuna göre, uyumluluk kaçıngan yaklaşımı \%5 oranında açıklamaktadır.

Değerlendirici yaklaşımın yordanmasına ilişkin yapılan basamaklı regresyon analizi sonuçlarına Tablo 10'da yer verilmiştir.

|Kastamonu Eğitim Dergisi, 27(6), 2019| 
Tablo 10. Değerlendirici yaklaşımın yordanması amacıyla gerçekleştirilen basamaklı regresyon analizi sonuçları

\begin{tabular}{|c|c|c|c|c|c|c|c|}
\hline Model & Değişken & & B & $\mathrm{SH}$ & $\beta$ & $\mathbf{t}$ & $\mathbf{p}$ \\
\hline \multirow{3}{*}{1} & (Sabit) & & 1.030 & .356 & & 2.891 & .004 \\
\hline & Uyumluluk & & .634 & .135 & .249 & 4.699 & .000 \\
\hline & $\mathrm{R}=.249$ & $\mathrm{R}^{2}=.062$ & $\Delta R^{2}=.059$ & & & & \\
\hline
\end{tabular}

Tabloda görüldüğü üzere, değerlendirici yaklaşımın yordanmasına ilişkin gerçekleştirilen basamaklı regresyon analizi sonucuna göre, uyumluluk ( $\beta=-.249$ ) değerlendirici yaklaşımın anlamlı bir yordayıcısıdır. Bir basamakta gerçekleşen regresyon analizinin sonucuna göre, uyumluluk değerlendirici yaklaşımı \%6 oranında açıklamaktadır.

Kendine güvenli yaklaşımın yordanmasına ilişkin yapılan basamaklı regresyon analizi sonuçlarına Tablo 11'de yer verilmiştir.

Tablo 11. Kendine güvenli yaklaşımın yordanması amacıyla gerçekleştirilen basamaklı regresyon analizi sonuçları

\begin{tabular}{|c|c|c|c|c|c|c|}
\hline Model & Değişken & B & SH & $\beta$ & $\mathbf{t}$ & $\mathbf{p}$ \\
\hline \multirow{3}{*}{1} & (Sabit) & .676 & .220 & & 3.071 & .002 \\
\hline & Kişisel Beceriler & .816 & .088 & .454 & 9.297 & .000 \\
\hline & $\mathrm{R}^{2}=.206$ & $\Delta \mathrm{R}^{2}=.204$ & $\mathrm{~F}_{(1,333)}=86.442 * *$ & & & \\
\hline \multirow{4}{*}{2} & (Sabit) & .527 & .226 & & 2.335 & .020 \\
\hline & Kişisel Beceriler & .633 & .112 & .352 & 5.648 & .000 \\
\hline & Genel Ruh Durumu & .254 & .098 & .162 & 2.592 & .010 \\
\hline & $\mathrm{R}^{2}=.222$ & $\Delta \mathrm{R}^{2}=.217$ & $\mathrm{~F}_{(2,332)}=47.322 * *$ & & & \\
\hline
\end{tabular}

$* * \mathrm{p}<.01, * \mathrm{p}<.05$

Kendine güvenli yaklaşımın yordanması amacıyla yapılan basamaklı regresyon analizi sonucuna göre, kişisel beceriler $(\beta=.352)$ ve genel ruh durumu ( $\beta=-.162)$ bu yaklaşımın anlamlı birer yordayıcısıdır. İki basamakta gerçekleşen regresyon analizinin ilk basamağında kişisel beceriler kendine güvenli yaklaşımı $\% 20$ oranında açıklarken, ikinci basamakta kişisel beceriler ile birlikte genel ruh durumu birlikte kendine güvenli yaklaşımı \%22 oranında açıkladığı görülmektedir.

Tablo 12'de planlı yaklaşımın yordanmasına ilişkin gerçekleştirilen basamaklı regresyon analizi sonuçlarına yer verilmiştir.

Tablo 12. Planlı yaklaşımın yordanması amacıyla gerçekleştirilen basamaklı regresyon analizi sonuçları

\begin{tabular}{|c|c|c|c|c|c|c|}
\hline Model & Değişken & B & SH & $\beta$ & $\mathbf{t}$ & $\mathbf{p}$ \\
\hline \multirow{3}{*}{1} & (Sabit) & 1.066 & .293 & & 3.633 & .000 \\
\hline & Uyumluluk & .577 & .111 & .274 & 5.193 & .000 \\
\hline & $\mathrm{R}^{2}=.075$ & $\Delta \mathrm{R}^{2}=.072$ & $\mathrm{~F}_{(1,333)}=26.971 * *$ & & & \\
\hline \multirow{4}{*}{2} & (Sabit) & .848 & .306 & & 2.771 & .006 \\
\hline & Uyumluluk & .442 & .125 & .210 & 3.544 & .000 \\
\hline & Genel Ruh Durumu & .242 & .103 & .138 & 2.339 & .020 \\
\hline & $\mathrm{R}^{2}=.090$ & $\Delta R^{2}=.084$ & $\mathrm{~F}_{(2,332)}=16.401 * *$ & & & \\
\hline
\end{tabular}

** $p<.01, * p<.05$

Tabloda görüldüğü üzere, uyumluluk $(\beta=.210)$ ve genel ruh durumu $(\beta=.138)$ planlı yaklaşımın anlamlı yordayıcıları olarak tespit edilmiştir. Tabloda görüldüğg̈ gibi, analiz iki basamakta gerçekleşmiştir. Analizin birinci basamağında planlı yaklaşımı \%7 oranında açıklayan uyumluluk yer alırken, ikinci basamakta uyumluluk ile birlikte \%1 oranında açıklayan genel ruh durumu bulunmaktadır. Her iki değişken planlı yaklaşımı birlikte $\% 8$ oranında açıklamaktadır.

\section{Sonuçlar ve Tartışma}

Gerçekleştirilen çalışmada öğretmen adaylarının problem çözme puanlarının iyi düzeyde olduğu belirlenmiştir. Bilindiği üzere öğretim programları 2005 yılında yapılandırmacı yaklaşıma göre güncellenmiş ve bu programlarda bireylere problem çözme becerisinin kazandırılması önemli görülmüştür. Günümüzde öğretmen adayı konumunda bulunan bireylerin çoğunlukla bu programlarla yetiştiği düşünüldüğünde, çalışmada ortaya çıkan sonuç öğretmen adaylarının eğitim geçmişlerinin ve yaşam deneyimlerinin olumlu bir yansıması olarak ifade edilebilir. Saracaloğlu, Yenice \& Kara- 
sakaloğlu (2009) tarafindan gerçekleştirilen çalışmada sını öğretmeni adaylarının problem çözme becerilerinin yeterli düzeyde olduğu bulunmuştur. Üstün ve Bozkurt (2003) tarafindan okul yöneticileriyle yapılan çalışmada ise okul yöneticilerinin problem çözme becerilerinin düşük düzeyde olduğu tespit edilmiştir. Karabulut ve Kuru (2009) tarafindan yapılan çalışmada ise beden eğitimi öğretmen adaylarının problem çözme becerilerinin orta düzeyde olduğu belirlenmiştir. Öğretmen adaylarının en çok kullandıkları problem çözme yaklaşımlarının planlı yaklaşım ve düşünen yaklaşım olduğu, bu yaklaşımların yanı sıra değerlendirici yaklaşım ve kendine güvenli yaklaşımı da sık sık kullandıkları tespit edilmiştir. Öğretmen adaylarının problem çözme becerisini olumsuz yönde etkileyen aceleci yaklaşım ve kaçıngan yaklaşımı ise nadiren kullandıkları sonucuna varılmıştır. Karabulut ve Kuru (2009) tarafindan yapılan çalışmada ise beden eğitimi öğretmen adaylarının problemler karşısında daha çok aceleci yaklaşım sergiledikleri belirlenmiştir.

Problem çözme ile ilgili yukarıda ulaşılan sonuç öğretmen adayları açısından olumlu bir sonuç olarak ifade edilebilir. Çünkü problem çözme düzeyinin yeterli olmadığı durumlarda çeşitli sorunlar yaşanabilmektedir. Sardoğan, Karahan \& Kaygusuz (2006) tarafindan yapılan çalışmada problem çözme becerisi düşük olan üniversite öğrencilerinin kararsızlık stratejilerini daha çok kullandıkları tespit edilmiştir. Bir başka ifadeyle, problem çözme becerisi düşük olan öğrenciler ya gerekli araştırmayı yapmadan en çok hoşlarına giden seçeneği seçerek hemen karar verirler ya da araştırma yapmalarına rağmen hangi seçeneğin doğru seçenek olduğu konusunda kesin bir karara varamamaktadırlar. Benzer şekilde, Deniz (2004) tarafindan yapılan çalışmada problem çözme ile karar verme arasında ilişki olduğu belirlenmiştir. Dixon, Heppner \& Anderson (1991) tarafindan yapılan çalışmada üniversite öğrencilerinin problem çözme becerileri düştükçe olumsuz yaşam stresi, intihar düşüncesi ve umutsuzluk düzeyinin arttğı ortaya çıkmıştr. D'zurilla, Chang, Nottingham \& Faccini (1998) tarafindan yapılan çalışmada problem çözme ile mutsuzluk, depresyon ve intihar riski arasında, D'Zurilla, Chang \& Sanna (2003) tarafından yapılan çalışmada problem çözme ile özsaygı ve saldırganlık arasında anlamlı ilişki olduğu belirlenmiştir.

Öğretmen adaylarının duygusal zekâ puanlarının "iyi” düzeyde olduğu belirlenmiştir. Alt boyutlar açısından incelendiğinde ise genel ruh durumu, kişilerarası beceriler ve kişisel becerileri boyutlarında "iyi", stres yönetimi ve uyumluluk boyutlarında ise "orta" düzeyde oldukları ortaya çıkmıştır. Bu sonuç öğretmen adaylarının uyumluluk ve stres yönetimi konularında eksiklikleri olduğunu göstermektedir. Öğretmen adayları öğrenimleri sırasında sınavlar, projeler, mezuniyet ve mesleğe atanma vb. stres oluşturabilecek çeşitli durumlarla karşı karşıya kalabilmektedir. Öğretmen adaylarının bu durumlarla fazlaca karşı karşıya kalmaları stres yönetimi puanlarının yüksek olmamasının bir nedeni olabilir. Erdem, İlğan ve Çelik (2013) tarafindan yapılan çalışmada öğretmenlerin en eksik oldukları duygusal zekâ boyutu stres yönetimi olarak bulunmuştur. Bu anlamda iki çalışmanın benzer sonuçlara ulaştı̆ı görülmektedir. Yalız (2013) tarafindan yapılan çalışmada erkek üniversite öğrencilerin stres yönetimi konusunda kadınlardan daha iyi olduklarını belirlemiştir. Yılmaz ve Özkan (2011) ile Sevindik, Uncu ve Güneş-Dağ (2012) tarafindan Sağıık Yüksekokulu öğrencileri ile yapılan çalışmalarda öğrencilerin duygusal zekâlarının "orta" düzeyde olduğu sonucuna ulaşılmış ve bu özelliklerinin geliştirilmesi gerektiği belirtilmiştir. Dutoğlu ve Tuncel (2008) tarafindan yapılan bir başka çalışmada öğretmen adaylarının duygusal zekâlarının beklenen düzeyin altında olduğu belirtilmiş ve bu sonuç sınıf atmosferi, öğretim yöntemleri/teknikleri ve materyalleri ile ilişkilendirilmiştir.

Çalışmada problem çözme ile duygusal zekâ arasında pozitif yönde orta düzeyde anlamlı bir ilişki olduğu tespit edilmiştir. Duygusal zekânın alt boyutları açısından incelendiğinde, problem çözmenin uyumluluk ve kişilerarası beceriler ile orta düzeyde, genel ruh durumu ve kişisel beceriler ile düşük düzeyde ilişkili olduğu görülmektedir. Deniz (2013) tarafindan öğretmen adaylarıyla, İşmen (2001) tarafindan lisans ve tezsiz yüksek lisans öğrencileri ile gerçekleştirilen çalışmalarda da duygusal zekâ ve problem çözme becerisi arasında pozitif yönde orta düzeyde bir ilişki tespit edilmiştir. Deniz ve Yılmaz (2016) tarafindan yapılan çalışmada da benzer bir sonuca ulaşılmış, üniversite öğrencilerinin duygusal zekâları ile problem odaklı stresle başa çıkma stilleri arasında düşük ve orta düzeyde ilişki olduğu belirlenmiştir. Yılmaz-Karabulutlu, Yılmaz ve Yurttaş'ın (2011) hemşirelik öğrencileriyle gerçekleştirdikleri çalışmada da duyguzal zekâ ve problem çözme becerisi arasında pozitif bir ilişki olduğu ortaya çıkmıştr. Alanyazın incelendiğinde duygusal zekâ ile eleştirel düşünce arasındaki ilişkinin ele alındığı çalışmaların (Küçük, 2007; Dutoğlu ve Tuncel, 2008; Erdem, illğan ve Çelik, 2013) bulunduğu ve bu çalışmalarda bireylerin bu iki özelliği arasında anlamlı ilişkilerin olduğu sonucuna ulaşıldığı görülmektedir. Problem çözmenin günlük yaşamdaki bir sorunu analiz etmek ve çözüm bulmak için eleştirel düşünmenin ve iletişim becerilerin uygulanması (Morreale, Osborn \& Pearson, 2000) olduğu düşünüldüğünde, bu çalışmaların sonuçları ile mevcut çalışmanın sonuçlarının tutarlı olduğu söylenebilir.

Problem çözme duygusal zekânın bütün alt boyutlarıyla ilişkili olmakla birlikte, sadece uyumluluk ve kişilerarası beceriler boyutları bağımsız şekilde problem çözmeyi yordamaktadır. Bu çalışmada kullanılan ölçeğin uyumluluk boyutunu oluşturan bileşenlerden birinin problem çözme olduğu görülmektedir (Acar, 2001; Bar-On, 2006). Diğer taraftan, kişilerarası zekâ başkalarının ruh hallerini ve mizaçlarını gözlemleyerek onların gelecekteki davranışlarını tahmin ede-

| Kastamonu Eğitim Dergisi, 27(6), 2019| 
bilme yeteneği olarak ifade edilmektedir (Salovey \& Mayer, 1990). Dolayısıyla, bu iki boyutta gelişmiş olan bireylerin problem çözme konusunda daha başarılı olmaları beklenen bir durum olarak ifade edilebilir. Diğer taraftan, bu sonuç problem çözme sürecinde duyguların, tutumların ve değerlerin önemli olduğunu teorik olarak ifade eden çalışmaları (Bingham, 2004; Dökmen, 2008; Heppner \& Krauskopf, 1987; Salovey, Mayer \& Caruso, 2002) destekler niteliktedir.

Problem çözme uyumluluk ve kişilerarası beceriler tarafindan \%14 oranında açıklanırken problem çözme yaklaşımları açısından farklı sonuçlara ulaşılmıştı. Duygusal zekânın boyutlarının en yüksek oranda açıkladığı problem çözme yaklaşımı \%22 ile kendine güvenli yaklaşım olarak belirlenmiştir. Kendine güvenli yaklaşımı açıklayan duygusal zekâ boyutları kişisel beceriler ve genel ruh durumu olarak ortaya çıkmıştır. Kişisel becerilerin en önemli bileşenlerinden biri özgüvendir. Genel ruh durumu boyutu ise, insan ilişkilerinde birleştirici ve problem çözmede etkili olma özelliklerini kapsamaktadır (Acar, 2001; Bar-On, 2006). Dolayısıyla bu iki boyutun kendine güvenli yaklaşımı açıklamasının anlaşılır olduğu söylenebilir. Duygusal zekâ boyutları tarafindan en çok açıklanan ikinci problem çözme yaklaşımı düşünen yaklaşımdır. Bu yaklaşım uyumluluk ve kişilerarası beceriler tarafindan $\% 15$ oranında açıklanmaktadır. Uyumluluk boyutunda gelişmiş olan bireylerin gerçekçi olma, kişilerarası becerileri gelişmiş bireylerin empati kurma özellikleri düşünüldüğünde (Acar, 2001; Bar-On, 2006) bu iki boyutun düşünen yaklaşımı yordaması anlamlı hale gelmektedir.

Planlı yaklaşım uyumluluk ve genel ruh durumu tarafindan \%8 oranında açıklanmaktadır. Duygusal zekânın uyumluluk boyutu değerlendirici yaklaşımı \%6, kaçıngan yaklaşımı \%5 oranında açıklamaktadır. Daha önce de ifade edildiği gibi uyumluluk boyutunun temel bileşenlerinden birisi problem çözmedir (Acar, 2001; Bar-On, 2006). Dolayısıyla uyumluluk boyutunda gelişmemiş bireylerin kaçıngan yaklaşımı daha çok tercih etmesi beklenen bir durumdur. Aceleci yaklaşım ise, kişisel beceriler ve kişilerarası beceriler tarafindan \%3 oranında yordanmaktadır. Kişisel beceriler benlik bilinci, özgüven, öz saygı ve bağımsızlık gibi boyutları içermekte ve bu becerileri gelişmiş kişiler kendilerini iyi ve yaptıklarını olumlu bulan kişiler olarak ortaya çıkmaktadır. Kişilerarası beceriler ise empati, sosyal beceriler ve sosyal sorumluluk boyutlarını içermektedir (Acar, 2001; Bar-On, 2006). Dolayısıyla, kişisel becerileri geliş̧miş kişilerin aceleci davranması, kişilerarası becerileri gelişmiş kişilerin ise aceleci olmaması anlaşılır bir durum olarak ifade edilebilir.

\section{5. Öneriler}

Araştırmada ulaşılan sonuçlar doğrultusunda aşağıdaki öneriler getirilebilir:

- Öğretmen adaylarının duygusal zekâ boyutlarından stres yönetimi ve uyumluluk boyutlarından iyi puan almadıkları düşünüldüğünde bu konularda desteklenmelerinin gerektiği söylenebilir.

- Duygusal zekâ ve problem çözme arasındaki anlamlı ilişkiler dikkate alındığında bireylerin problem çözme becerilerinin geliştirilmesi için duygusal olarak desteklenmeleri ve duygusal zeka ile ilgili bilgilendirilmeleri gerektiği söylenebilir.

- Bu çalışma öğretmen adaylarıyla sınırıdır. Benzer çalışmalar eğitim sisteminin diğer önemli paydaşları olan öğrenciler, öğretmenler, yöneticiler vb. çalışma gruplarıyla yapılabilir.

\section{Kaynakça}

Acar, F. T. (2001). Duygusal zekâ yeteneklerinin göreve yönelik ve insana yönelik liderlik davranışları ile ilişkisi: Banka şube müdürleri üzerine bir alan araştırması. İstanbul Üniversitesi, Sosyal Bilimler Enstitüsü, İstanbul.

Balcı, A. (2010). Sosyal bilimlerde araştırma: Yöntem, teknik ve ilkeler. Ankara: Pegem A Yayıncılık.

Bar-On, R. (2006). The Bar-On model of emotional-social intelligence (ESI) 1. Psicothema, 18(Suplemento), 13-25.

Bingham, A. (2004). Çocuklarda problem çözme yeteneklerinin geliştirilmesi. İstanbul: MEB Yayınları.

Büyüköztürk, Ş., Çakmak, E., Akgün, Ö.E., Karadeniz, Ş., \& Demirel, F. (2013). Bilimsel araşttrma yöntemleri (14. Baskı). Ankara: Pegem Akademi.

Deniz, M. E. (2004). Üniversite öğrencilerinin karar vermede öz saygı karar verme stilleri ve problem çözme becerileri arasındaki ilişkinin incelenmesi üzerine bir araştırma. Eğitim Araştırmaları Dergisi, 4(15), 23-35.

Deniz, M. E., \& Yılmaz, E. (2016). Üniversite öğrencilerinde duygusal zeka ve stresle başa çıkma stilleri arasındaki ilişkinin incelenmesi. Türk Psikolojik Danışma ve Rehberlik Dergisi, 3(25), 17-26.

Deniz, S. (2013). The relationship between emotional intelligence and problem solving skills in prospective teachers. Educational Research and Reviews, 8(24), 2339-2345.

Dewey, J. (1997). How we think. Boston: D. C. Heath \& Co. Publishers.

Dixon, W. A., Heppner, P. P., \& Anderson, W. P. (1991). Problem-solving appraisal, stress, hopelessness, and suicide ideation in a college population. Journal of Counseling Psychology, 38(1), 51-56.

Dökmen, Ü. (2008). Sanatta ve günlük yaşamda iletişim çatş̧maları ve empati. İstanbul:Remzi Kitabevi. 
Dutoğlu, G., \& Tuncel, M. (2008). Aday öğretmenlerin eleştirel düşünme eğilimleri ile duygusal zeka düzeyleri arasındaki ilişki. Abant İzet Baysal Üniversitesi Eğitim Fakültesi Dergisi, 8(1), 11-32.

D’Zurilla, T. J., Chang, E. C., Nottingham IV, E. J., \& Faccini, L. (1998). Social problem-solving deficits and hopelessness, depression, and suicidal risk in college students and psychiatric inpatients. Journal of clinical psychology, 54(8), 1091-1107.

D'zurilla, T. J., Chang, E. C., \& Sanna, L. J. (2003). Self-esteem and social problem solving as predictors of aggression in college students. Journal of Social and Clinical Psychology, 22(4), 424-440.

Gelbal, S. (1991). Problem çözme. Hacettepe Üniversitesi Eğitim Fakültesi Dergisi, 6(6), 167-173.

Güllüce, A. Ç., \& İ̧scan, Ö. F. (2010). Mesleki tükenmişlik ve duygusal zekâ arasındaki ilişki. Eskişehir Osmangazi Üniversitesi iiBF Dergisi, 5(2), 7-29.

İşmen, A. E. (2001). Duygusal zekâ ve problem çözme. M.Ü. Atatürk Eğitim Fakültesi Eğitim Bilimleri Dergisi, 13, $111-124$.

Heppner, P. P., \& Krauskopf, C. J. (1987). An information-processing approach to personal problem solving. The Counseling Psychologist, 15(3), 371-447.

Heppner, P. P., \& Petersen, C. H. (1982). The development and implications of a personal problem solving inventory. Journal of Counseling Psychology, 29, 66-75.

Karaalioğlu, Z. (2015). Spss'de output analizi. İstanbul Ticaret Üniversitesi, Sosyal Bilimler Enstitüsü, İstanbul.

Karabulut, E. O., \& Kuru, E. (2009). Ahi Evran Üniversitesi beden eğitimi öğretmenliği bölümü öğrencilerinin problem çözme becerileri ile kişilik özelliklerinin çeşitli değişkenler bakımından incelenmesi. Ahi Evran Üniversitesi Kırşehir Eğitim Fakültesi Dergisi, 10(3), 119-127.

Korkut, F. (2002). Lise öğrencilerinin problem çözme becerileri. Hacettepe Üniversitesi Eğitim Fakültesi Dergisi, 23(23), $177-184$.

Küçük, G. (2007). Aday öğretmenlerin eleştirel düşünme becerileri ile duygusal zeka düzeyleri arasındaki ilişki (Yayınlanmamış Yüksek Lisans Tezi). Abant İzzet Baysal Üniversitesi, Sosyal Bilimler Enstitüsü, Bolu.

Lee, S., Jung, H., \& Jung, H. (2017). The Effective Learning Strategies through the Analysis of Computer Learners' Problem-Solving Skills. International Information Institute (Tokyo). Information, 20(5A), 3047-3054.

Mayer, J. D. (2004). What is emotional intelligence?. UNH Personality Lab. 8.

Morgan, C. T. (1974). A brief introduction to psychology. New York: McGraw-Hill.

Morreale, S. P., Osborn, M. M., \& Pearson, J. C. (2000). Why communication is important: A rationale for the centrality of the study of communication. Journal of the Association for Communication Administration, 29, 1-25.

Polya, G. (2004). How to solve it: A new aspect of mathematical method (No. 246). New Jersey/Princeton: Princeton University Press.

Sahin, N., Sahin, N. H., \& Heppner, P. P. (1993). Psychometric properties of the problem solving inventory in a group of Turkish university students. Cognitive Therapy and Research, 17(4), 379-396.

Salovey, P., \& Mayer, J. D. (1990). Emotional intelligence. Imagination, cognition and personality, 9(3), $185-211$.

Salovey, P., Mayer, J. D., \& Caruso, D. (2002). The positive psychology of emotional intelligence. C. R. Snyder, S. J. Lopez (Ed). The Handbook of positive psychology içinde. New York: Oxford University Press.

Sardoğan, M. E., Karahan, T. F., \& Kaygusuz, C. (2006). Üniversite öğrencilerinin kullandıkları kararsızlık stratejilerinin problem çözme becerisi, cinsiyet, sınıf düzeyi ve fakülte türüne göre incelenmesi. Mersin Üniversitesi Eğitim Fakültesi Dergisi, 2(1), 78-97.

Saracaloğlu, A. S., Serin, O., \& Bozkurt, N. (2001). Dokuz eylül üniversitesi eğitim bilimleri enstitüsü öğrencilerinin problem çözme becerileri ile başarıları arasındaki ilişki. M.Ü. Atatürk Eğitim Fakültesi Eğitim Bilimleri Dergisi, 14, 121-134.

Saracaloğlu, A. S., Yenice, N., \& Karasakaloğlu, Ö. G. D. N. (2009). Öğretmen Adaylarının İletişim ve Problem Çözme Becerileri ille Okuma İlgi ve Alışkanlıkları Arasındaki İlişki. Yüzüncü Yıl Üniversitesi Eğitim Fakültesi Dergisi, 6(2), 187-206.

Sevindik, F., Uncu, F., \& Güneş-Dağ, D. (2012). Sağlık yüksekokulu öğrencilerinin duygusal zekâ düzeylerinin bazı değişkenler açısından incelenmesi. Fırat Üniversitesi Sağlık Bilimleri Tıp Dergisi, 26(1), 21-26.

Tümkaya, S., \& ifflazoğlu, U. A. (2000). Ç. Ü. sınıf öğretmenliği öğrencilerinin otomatik düşünce ve problem çözme düzeylerinin bazı sosyo demografik değişkenlere göre incelenmesi. Çukurova Üniversitesi Sosyal Bilimler Enstitüsü Dergisi, 6(6), $143-158$.

Üstün, A., \& Bozkurt, E. (2003). Illköğretim okulu müdürlerinin kendilerini algılayışlarına göre problem çözme becerilerini etkileyen bazı mesleki faktörler. Kastamonu Eğitim Dergisi, 11(1), 13-20.

Yalız, D. (2013). Anadolu Üniversitesi Beden Eğitimi ve Spor Öğretmenliği Bölümü Öğrencilerinin Duygusal Zeka Düzeyleri. Pamukkale Journal of Sport Sciences, 4(2), 94-111.

Yılmaz, E., \& Özkan, S. (2011). Hemşirelik öğrencilerinin duygusal zekâ düzeylerinin bazı değişkenler açısından incelenmesi. Maltepe Üniversitesi Hemşirelik Bilim ve Sanat Dergisi, 4(1), 39-5.

Yılmaz-Karabulutlu, E., Yılmaz, S., \& Yurttaş, A. (2011). Öğrencilerin duygusal zekâ düzeyleri ile problem çözme becerileri arasındaki ilişki. Psikiyatri Hemşireliği Dergisi, 2(2), 75-79. 